The resolution was laid over under the rule and called up March 21 and was adopted. The same day it was messaged over to the Senate. On March 22 Senator William Carden of Henry County called up the resolution for consideration and moved its adoption. The motion prevailed and the resolution was adopted.

This is a small yellow bird popularly known as the wild canary. The male is bright yellow with black wings and tail and black top of head; the female is similarly marked, but not so brilliant. They are fairly common permanent residents in the southern part of the state, but less numerous in the north. They are often seen in flocks in undulating flight.

\title{
LONGEST LEGISLATIVE SERVICE IN IOWA
}

Attention has been called recently as to who in the history of the state has given longest service in the legislative branch of our government. The summary below shows the interesting facts.

William Larrabee, afterward governor, was a member of the Senate continuously from 1868 to 1886 , or eighteen years.

David W. Kimberly of Davenport was a member of the House of Representatives four years, 1915 to 1919, and of the Senate sixteen years, 1919 to 1935 , thus giving twenty years of continuous service in one or the other of the two branches.

John L. Wilson of Clinton was a member of the House of Representatives four years, 1894 to 1898 , and of the Senate seventeen years, 1898 to 1915 , giving twenty-one years of continuous service in one or the other branches.

No other legislator has equalled the length of service of any one of these three members excepting Lemuel R. Bolter of Logan, and he exceeded them, as he served in one or the other branch for eleven assemblies, twenty-two years, but his service was not continuous, and was between 1866 and 1902 .

Senator Kimberly was re-elected last November and if he serves his coming four-year term he will have completed twentyfour years of continuous service in one or the other chamber of the assembly, and will exceed in length the service of any other member. 
Copyright of Annals of Iowa is the property of State of Iowa, by \& through the State Historical Society of Iowa and its content may not be copied or emailed to multiple sites or posted to a listserv without the copyright holder's express written permission. However, users may print, download, or email articles for individual use. 